\title{
In search of higher persistence rates in distance education online programs
}

\author{
Alfred P. Rovai* \\ School of Education, Regent University, 1000 Regent University Drive, Virginia Beach, VA 23464-9800, USA
}

Received 15 July 2002; received in revised form 2 October 2002; accepted 1 November 2002

\begin{abstract}
Tinto's [Rev. Educ. Res. 45 (1975) 89; Tinto, V. (1987). Leaving college. Chicago: The University of Chicago Press; Tinto, V. (1993). Leaving college: rethinking the causes and cures of student attrition. Chicago: The University of Chicago Press] student integration model and Bean and Metzner's [Rev. Educ. Res. 55 (1985) 485] student attrition model have been influential in explaining persistence and attrition in higher education programs. However, these models were developed with on-campus programs in mind and, although they are broadly relevant to distance education programs, their ability to explain the persistence of online students is limited. Distance education students have characteristics and needs that differ from traditional learners and the virtual learning environment differs in important ways from an on-campus environment. This article draws chiefly from Tinto's and Bean and Metzner's models and the results of research into the needs of online distance education students in order to synthesize a composite model to better explain persistence and attrition among the largely nontraditional students that enroll in online courses.

(C) 2002 Elsevier Science Inc. All rights reserved.
\end{abstract}

Keywords: Persistence; Dropout; Retention; Attrition; Online; Distance education; Adult education

\section{Introduction}

Persistence, that is, the behavior of continuing action despite the presence of obstacles, is an important measure of higher education program effectiveness. Applied to adult education,

* Tel.: +1-757-226-4861; fax: +1-757-226-4857.

E-mail address: alfrrov@regent.edu (A.P. Rovai). 
persistence can be defined as the length of time an adult attends classes (Quigley, 1997). Adults choose to participate in educational programs to meet their learning goals while school children participate because of mandatory attendance requirements. Consequently, the persistence rates of adults in postsecondary programs are often substantially lower than children attending public schools and are strongly related to the ability of educational programs to satisfy adult needs.

College enrollment in the United States is on the increase. Snyder and Hoffman (2002) reported enrollment in public and private degree-granting institutions increased by 17\% between 1979 and 1989. Moreover, enrollment increased 9\% between 1989 and 1999 despite a slight decline in enrollment from 1992 to 1995 . They also reported that the persistence of undergraduate students who enrolled in 4-year colleges in 1995-1996 was $77 \%$ by spring 1998 . That is, $23 \%$ of students who started their undergraduate studies in fall 1995 had withdrawn from school by spring 1998. Historically, most undergraduate students are from the traditional student population, that is, students who entered college immediately after graduating from high school and attended college fulltime.

Horn and Premo (1995) analyzed data from the 1992-1993 National Postsecondary Student Aid Study and reported that the traditional path to a college degree, generally viewed as enrolling in college immediately after high school and attending full-time until graduation, is becoming the exception rather than the rule. They pointed out that in $1992-$ 1993, for example, although $57 \%$ of undergraduates had enrolled in postsecondary schools immediately after high school graduation, only about one-third attended full-time for the full 1992-1993 academic year. They cited these statistics as evidence that the US is moving toward a higher proportion of nontraditional students in its postsecondary programs. Furthermore, Villella and $\mathrm{Hu}$ (1991) reported that persistence for nontraditional students in on-campus programs was approximately $68 \%, 9$ percentage points lower than for all undergraduate students.

The definition of a nontraditional student has been the source of much discussion in the professional literature. Bean and Metzner (1985) identified age, especially being over 24, as one of the most common variables in studies of nontraditional student attrition. Students over 24 years old represent a population of adult learners who often have family and work responsibilities that can interfere with successful attainment of educational goals. Other characteristics typically used to characterize nontraditional students are part-time student status and full-time employment.

The lower persistence of nontraditional students in college has implications for distance education, since students enrolled in programs at a distance are typically viewed as nontraditional. For example, Wood (1996) reported over $70 \%$ of recent graduates enrolled in distance education programs were employed in full-time jobs. Carr (2000) noted that persistence in distance education programs is often 10-20 percentage points lower than in traditional programs. She also reported significant variation among institutions; with some postsecondary schools reporting course-completion rates of more than $80 \%$ and others finding that fewer than $50 \%$ of distance education students finish their courses. 
Persistence is an issue of increasing importance for both traditional and distance education programs in view of the increasing enrollments of nontraditional students in both programs. Moreover, Borrego (2002) wrote that the US Department of Education is placing added importance on higher education retention issues. She reported that US President Bush's emphasis on quality through the examination of outcomes-based education could extend to the postsecondary level with added emphasis placed on persistence. She also reported that the US Department of Education intends to examine retention policies and examine ways to use federal money as an incentive to reward programs that work. The need therefore exists to examine ways of increasing persistence in postsecondary programs because of: (a) the increase in numbers of nontraditional students and the lower retention rates typically associated with these students; (b) the increase in the number distance education programs that typically consist of nontraditional students; and (c) the added importance that the US federal government places on student retention. Accordingly, this article analyzes several influential models used to explain the persistence of adult learners and the results of research into the needs of online students in order to show that existing persistence models are not entirely suitable for use with an online population of adult learners. Information is then synthesized into a composite model that better explains persistence and attrition among the largely nontraditional students that enroll in online courses and programs.

\section{Psychological models of persistence}

During the past few decades, several theoretical models of higher education student persistence have emerged. The earliest attempts to explain persistence were based on psychological models. These models (e.g., Fishbein \& Ajzen, 1975) theorized that a student's decision to persist is largely based on previous behavior, attitudes, and norms that drive behavior through the formation of intent to learn. Corno and Kanfer (1993) suggested that volition is the mediating force between intentions to learn and behaviors to learn. Accordingly, they defined volition as those thoughts and behaviors that are directed toward maintaining one's intention to attain a specific goal in the face of distractions. Heckhausen and Kuhl (1985) depicted volition as a psychological state characterized by thoughts about the implementation of goals into action and emphasized self-regulation in the context of persistence. They asserted that motivation may be sufficient for students to enroll in educational programs, but students in programs that require sustained effort may encounter declining motivation, particularly in the face of adversity. At this point, volitional processes become important in explaining persistence.

More recent models, although grounded in these psychological models, explain persistence and attrition through student-institution "fit" by looking at student, institutional, and environmental variables and specific themes, such as the social integration of students into campus life. Two important and influential models in this genre were developed by Tinto $(1975,1987,1993)$ and by Bean and Metzner (1985). 


\section{Tinto's student integration model}

Perhaps, the most influential attempt to explain the process of persistence in higher education as a function of student-institution "fit" was put forward by Tinto (1975, 1987, 1993) (see Fig. 1). He theorized that the primary determinants of successful persistence can be broken down into: (a) factors that are drawn from experiences prior to college and individual student characteristics and (b) factors that are drawn from experiences at college. Experiences before college and student characteristics are input variables that cannot be affected greatly by schools. However, student experiences subsequent to admission, which Tinto referred to as "integration" variables, are affected by school policies and practices. Tinto (1987, p. 123) suggested that "the more central one's membership is to the mainstream of institutional life the more likely, other things being equal, is one to persist." Typically, postsecondary education persistence studies find that academic integration has an important impact on persistence (Pascarella \& Terenzini, 1991). Consequently, persistence is often viewed as a measure of how well students integrate into a particular school.

Tinto's student integration model explains the student integration process as mostly a function of academic and social experiences in college. He measured successful academic integration by grade point average (GPA) and evaluated social integration by the development and frequency of positive interactions with peers and faculty and involvement in extracurricular activity. Tinto found that integration along these two dimensions

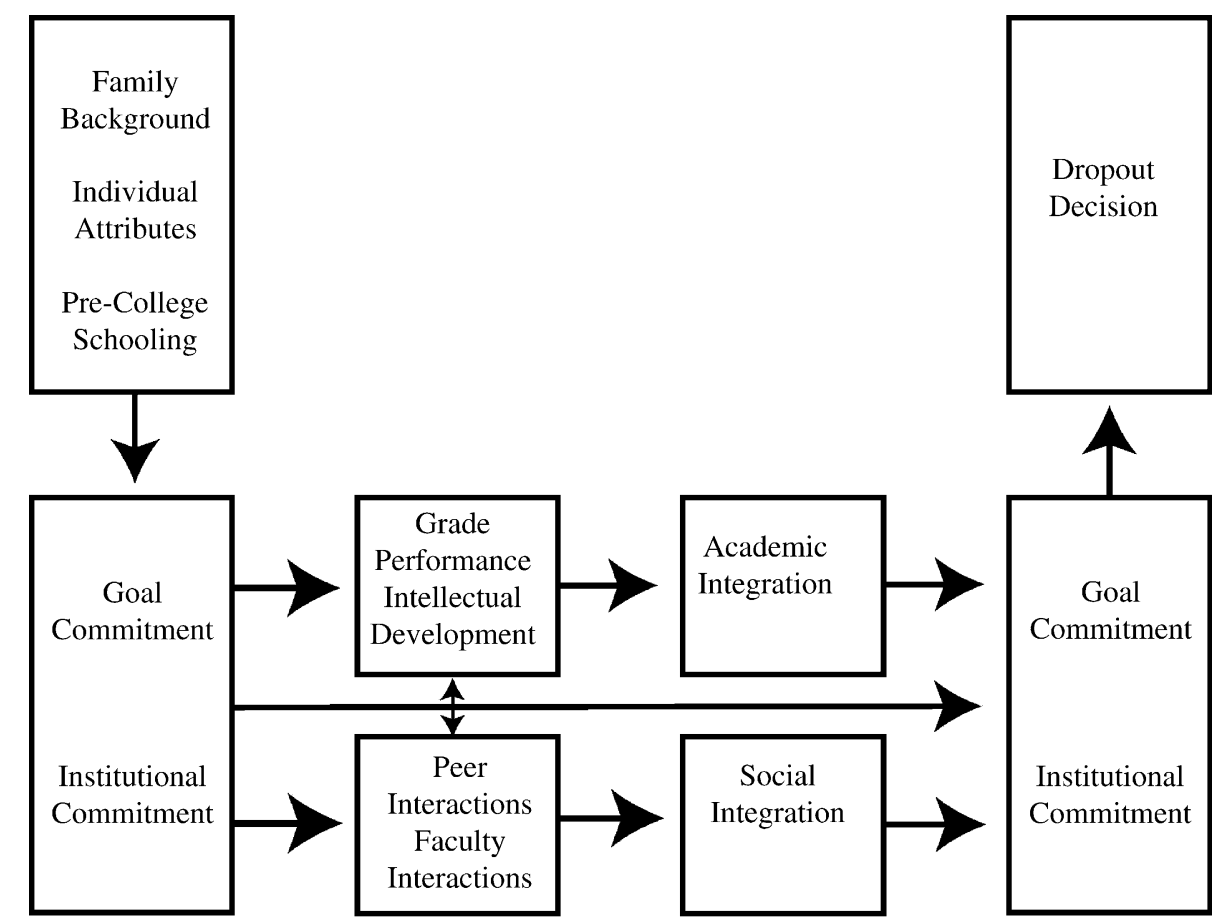

Fig. 1. A conceptualization of Tinto's $(1975,1987,1993)$ student integration model. 
produced stronger student commitment to their specific institutions and increased their persistence. He wrote,

In the final analysis, it is the interplay between the individual's commitment to the goal of college completion and his [or her] commitment to the institution that determines whether or not the individual decides to dropout from college and the forms of dropout behavior the individual adopts. Presumably, either low goal commitment or low institutional commitment can lead to dropout. (Tinto, 1975, p. 96)

Tinto also argued that insufficient interactions with peers and faculty and differences with the prevailing value patterns of other students are likely to result in dropouts. In other words, students who feel they do not "fit in" and have low sense of community tend to feel isolated and are at-risk of withdrawing. He asserted "a person will tend to withdraw from college when he [or she] perceives that an alternative form of investment of time, energies, and resources will yield greater benefits, relative to costs, over time than will staying in college" (1975, p. 98). If external activities become more attractive than college completion, a student will drop out. The more a student's experiences serve to integrate the student socially and intellectually into the life of the college, the more likely the student is to persist until degree completion. In more recent works, Tinto (1987, 1993) emphasized the importance of learning communities that facilitate collaborative work so that students learn together rather than apart and the use of classroom assessment techniques that encourage discourse about learning.

Tinto's model validates the need for schools to assume a proactive role in a student's integration process. Accordingly, many colleges include a "freshman experience" orientation that Koutsoubakis (1999) showed can increase persistence. These orientations are used to: (a) assist new freshmen in making the transition from high school to college; (b) orient students to the services and culture of the college and its campus; and (c) integrate students into an intellectual community of students and faculty. Additionally, Hashway, Baham, Hashway, and Rogers (2000) provided evidence that completion of remedial education programs increased first-year retention rates among academically at-risk students. Positive effects were also found for students completing a summer transition program (Wolf-Wendel, Tuttle, \& Keller-Wolff, 1999).

However, educators who desire to study the persistence of nontraditional students may find that the Tinto's model has limited applicability since it is best suited to institutional analysis of the persistence of traditional undergraduate students (Maxwell, 1998; Rendon, Jalomo, \& Nora, 2000). Tinto's model is not as useful for studying the attrition of older students, for whom academic and social integration within the university may be less influential (Bean \& Metzner, 1985). Additionally, Yorke (1999) suggested that Tinto's theory has relatively little to say about the impact of external factors in shaping students' perceptions, commitments, and reactions that he feels are important. Nonetheless, the work of Tinto $(1975,1987,1993)$ has been particularly important in establishing the role of the school in promoting an environment for student integration and remains relevant in this regard. 


\section{Bean and Metzner's student attrition model}

As mentioned above, distance education students are very likely to be nontraditional, and even traditional programs are moving toward higher numbers of nontraditional students. As nontraditional students become a more prominent segment of the student body, researchers must examine whether the findings of research on the persistence of traditional college students hold true for nontraditional students as well. This is especially important regarding the notion of social integration. Nontraditional students are usually associated with living away from campus, belonging to social groups that are not associated with the college, having dependents, not being involved in campus organizations, and attending college part-time. Because these students manage their time among their classes, work, families, and roles in the community, there is often little time for campus involvement outside the classroom (Graham \& Gisi, 2000).

Bean and Metzner (1985) proposed a model (see Fig. 2), grounded on Tinto's model and earlier psychological models, to explain attrition of nontraditional students, whom they defined as "older than 24 , does not live in a campus residence (i.e., is a commuter), or is a

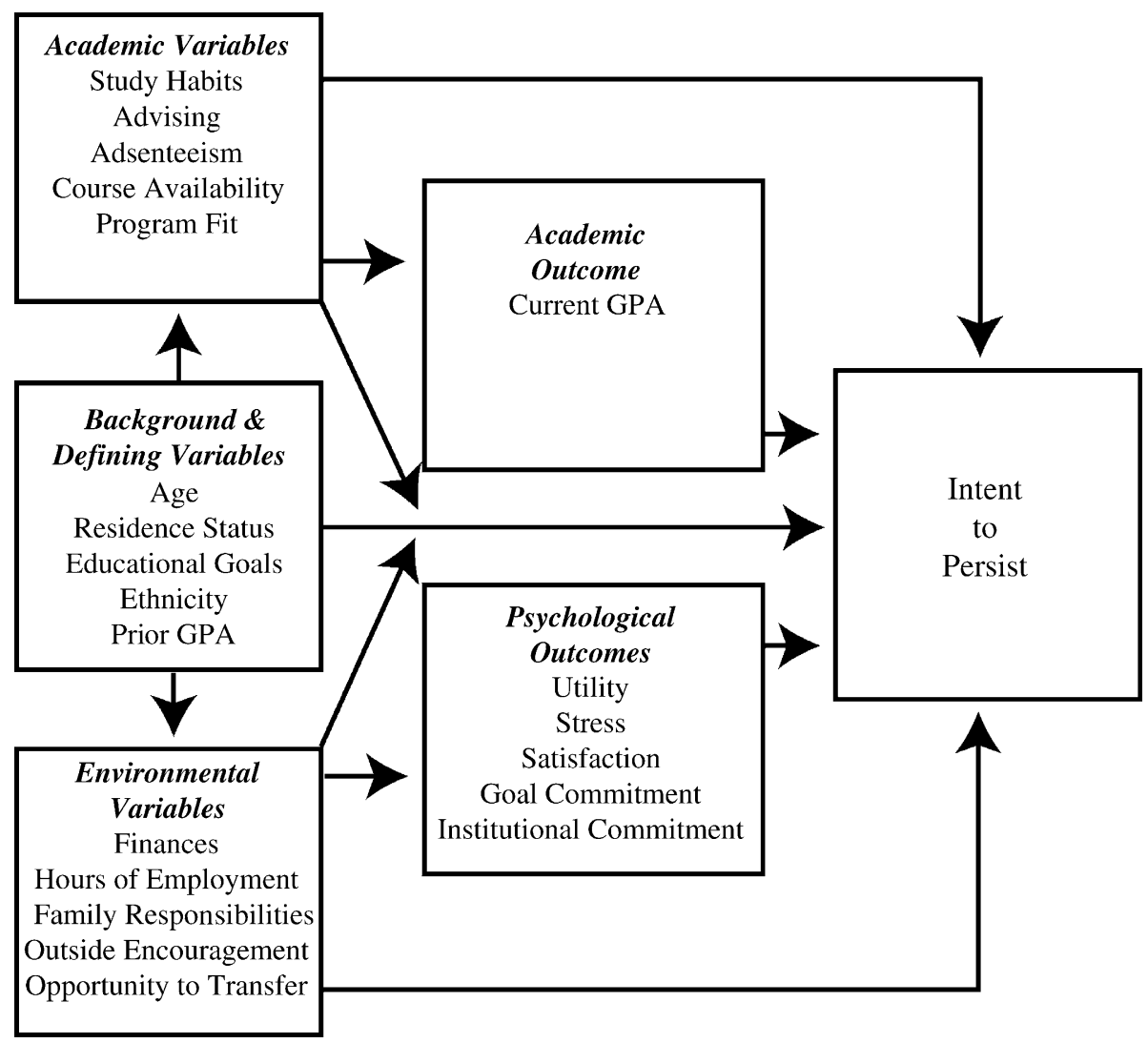

Fig. 2. A conceptualization of Bean and Metzner's (1985) student attrition model. 
part-time student, or some combination of these three factors; is not greatly influenced by the social environment of the institution, and is chiefly concerned with the institution's academic offerings (especially courses, certification and degrees)" (p. 489). They argued that older students have different support structures than younger students and since they have limited interaction with other groups within the college community they draw more support from outside the academic environment "because their reference group of peers, friends, family, and employers exists outside the institution" (p. 506). This is in contrast to traditional students, where on-campus students and faculty represent their most important support group. Accordingly, Bean and Metzner's model is more relevant than Tinto's model in explaining the persistence of distance education students.

As with Tinto's model, Bean and Metzner's (1985) model attempts to predict student persistence based on student-institution "fit." In analyzing attrition factors for nontraditional students, Bean and Metzner identified four factors that affect persistence: (a) academic variables such as study habits and course availability; (b) background and defining variables such as age, educational goals, ethnicity, and prior GPA; (c) environmental variables such as finances, hours of employment, family responsibilities, and outside encouragement; and (d) academic and psychological outcomes while at the college. In particular, they concluded that "students' reports of financial difficulty were positively related to attrition from college" and "many older students expressed concern about the ability to finance a college education" (p. 503). These variables, many of which are outside the control of the school, may push students out of school by putting too much pressure on their time, resources, and sense of well being. In more recent research, Metzner and Bean (1987) found that while integration variables were not significant for nontraditional students, GPA and institutional commitment directly affected persistence through their impact on perceptions of a postsecondary education's usefulness in gaining employment, satisfaction, and opportunity to transfer.

Based solely on a student satisfaction survey, Parker and Greenlee (1997) studied persistence at a suburban university in southeastern Virginia that consisted of a commuteroriented student body, a high percentage of nontraditional students, and low to moderate admissions criteria. They reported that, in order of importance, financial problems, followed by family complications, work schedule conflicts, and poor academic performance were the most important factors that explained why students did not persist. These findings support the importance of environmental variables in Bean and Metzner's model.

Henry and Smith (1993, p. 29) interpreted this model as follows:

When both academic and environmental variables are favorable, students should persist. When both variables are unfavorable, students are likely to dropout. When academic variables are positive, but environmental variables are negative, the favorable effects of academic variables on student goal attainment are suppressed or attenuated... Students may dropout of college despite strong academic performance if they perceive low levels of utility, satisfaction, or goal commitment, or if they experience high levels of stress.

Cabrera, Castaneda, Nora, and Hengstler (1992) found significant overlap between the models of Tinto $(1975,1987,1993)$ and Bean and Metzner (1985). They confirmed the 
positive effects that commitment to the school, goal commitment, and social integration (Tinto, 1975) had on persistence and affirmed the impact that forces external to the institution (Bean \& Metzner, 1985) also had on student attrition. Thus, they identified two highly significant predictors, one from each model, to help explain persistence. They concluded that the interplay between institutional, personal, and external factors needed to be considered in developing programs to increase persistence. Furthermore, in a study of nontraditional adult students, Ashar and Skenes (1993, p. 96) found that "classes that were professionally more homogeneous, and thus socially more integrated, and smaller classes lost fewer students than less socially integrated and larger classes." These results provide additional evidence that social integration, a component of Tinto's model, is also relevant for nontraditional students. Consequently, a synthesis of Tinto's and Bean and Metzner's models may be a better predictor of the persistence of nontraditional adult students than either model by itself. However, these two models were designed with traditional course delivery in mind, that is, traditional and nontraditional students who attended classes on campus. Although they are relevant for online programs, they should be adapted to the needs of online learners in order to better explain persistence and attrition in distance education programs.

\section{Composite persistence model}

Fig. 3 synthesizes the persistence models of Tinto $(1975,1987,1993)$ and Bean and Metzner (1985) with the skills required by online students (Rowntree, 1995; Cole, 2000), the special needs of distance education students (Workman \& Stenard, 1996), and the requirement to harmonize learning and teaching styles (Grow, 1996) into a single composite model. This model is divided into student characteristics and skills prior to admission and external and internal factors affecting students after admission.

\subsection{Student characteristics prior to admission}

Student characteristics such as age, ethnicity, gender, intellectual development, and academic performance and preparation prior to college can affect student persistence (Bean \& Metzner, 1985). For example, minority students may feel isolated in online courses, a risk factor associated with dropouts. Murguia, Padilla, and Pavel (1991) found that social integration into college was enhanced for ethnic groups when they had ethnic clubs or enclaves available.

Ross and Powell (1990) reported that females tend to be more successful in online courses than males. Rovai (2001) found similar gender-related differences in an online course and explained them as differences in communication patterns and sense of community. He found that the majority of men (and some women) exhibited an independent voice and the majority of women (and some men) used a connected voice in the communication patterns of messages they wrote. Those with the highest sense of community were more likely to write messages using a connected voice while those with the lowest sense of community tended to write messages using the independent voice. Low sense of community, which is related to 


\section{Prior to Admission}

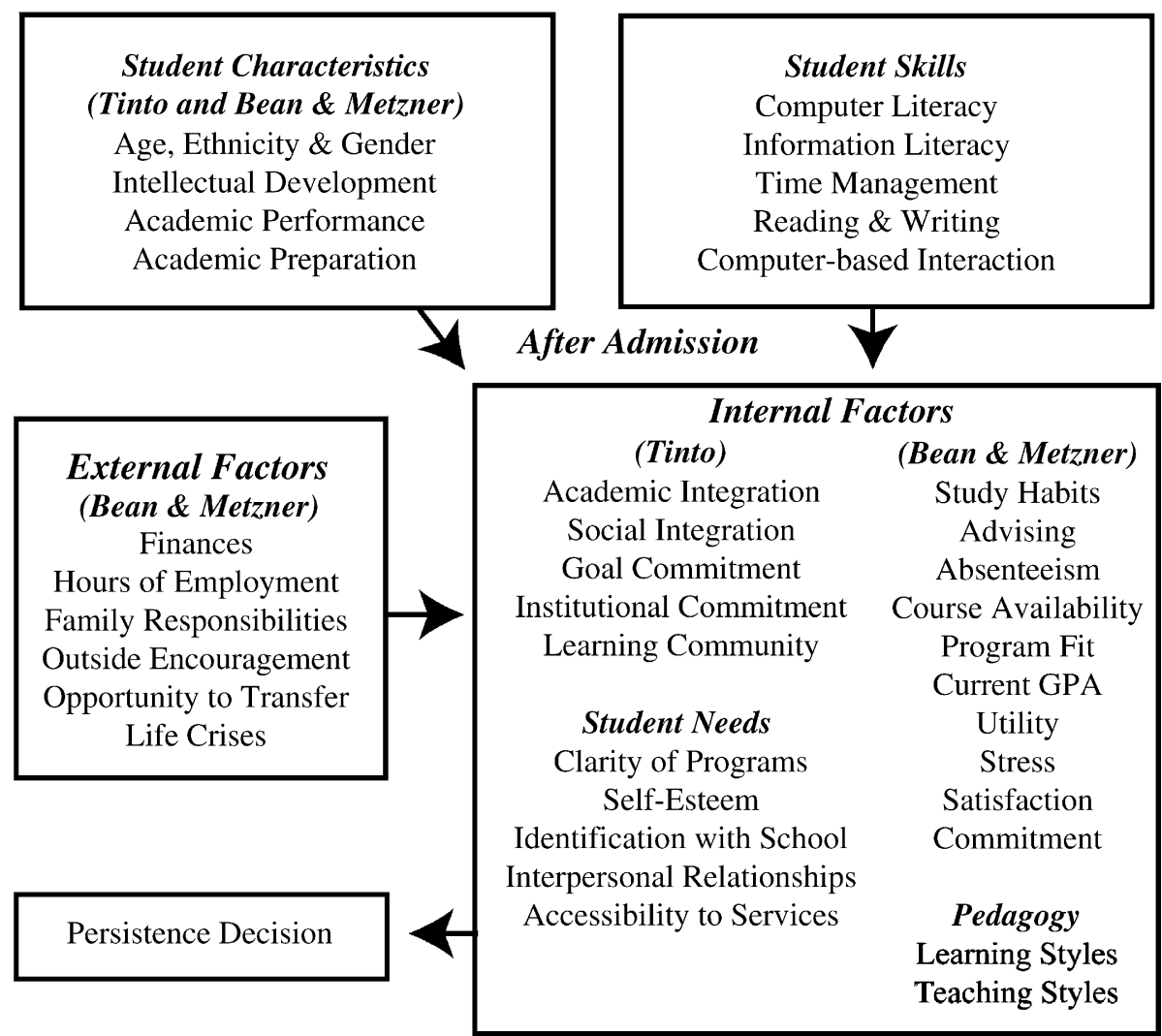

Fig. 3. A composite persistence model that synthesizes the persistence models of Tinto $(1975,1987,1993)$ and Bean and Metzner (1985) together with relevant research in online student skills (Rowntree, 1995; Cole, 2000) and needs (Workman \& Stenard, 1996) and the requirement to harmonize learning and teaching styles (Grow, 1996) to explain student persistence in online distance education programs.

feelings of disconnectedness and isolation, is believed to adversely affect student persistence in online courses.

Several researchers also noted a significant relationship between previous academic performance and completion of distance learning courses. Schlosser and Anderson (1994) explained this relationship by theorizing that students who completed more formal education or received higher grades had more fully developed research and study skills and more realistic expectations of the requirements and the effort needed to fulfill their educational goals.

\subsection{Student skills prior to admission}

Successful learning at a distance using the Internet also requires special student skills. Rowntree (1995) claimed that students require skills in: (a) computing, (b) literacy discussion, 
(c) time management, and (d) interpersonal interaction. He also observed that the focus in online learning is often less on the content than it is on the cognitive process of "offering up ideas, having them criticized or expanded on, and getting the chance to reshape them (or abandon them) in the light of peer discussion" (p. 207). Additionally, Cole (2000) identified the added importance that online distance education placed on reading and writing skills and the need for online students to have strong skills in these areas. Since online students largely work independently, they also need the information literacy skills to "recognize when information is needed and have the ability to locate, evaluate, and use effectively the needed information" (American Library Association Presidential Committee on Information Literacy, 1989, p. 1). Deficiencies in these special skills can lead to academic difficulties and attrition.

\subsection{External factors affecting students after admission}

Naturally, the experiences of students subsequent to college admission can have a profound effect on a student's persistence decision (Tinto, 1975). These experiences are divided into external and internal factors. The external factors of the composite model draw heavily from the environmental variables contained in Bean and Metzner's (1985) model, such as finances, hours of employment, family responsibilities, and outside encouragement. Tinto (1993) also acknowledged that going to college might be only one of many obligations that a student will have. Consequently, he suggested that persistence might be seriously weakened by external factors when institutional academic and social systems are weak. Accordingly, additional demands on the time of nontraditional students such as life crises, e.g., sickness, divorce, loss of a job, etc., can adversely affect persistence.

\subsection{Internal factors affecting students after admission}

Many of the internal factors were taken from Tinto's $(1975,1987,1993)$ and Bean and Metzner's (1985) models as described above. However, both Tinto and Bean and Metzner conceptualized integration from the perspective of college students who attended class on campus. The research literature suggests that students who take classes at a distance have additional needs, and these needs are also depicted in Fig. 3 as internal factors.

Workman and Stenard (1996) analyzed the needs of distance learners and identified five specialized needs. The degree to which these needs are satisfied will also influence the persistence of online students. The first need is consistency and clarity of online programs, policies, and procedures. Distance learners may not have a good understanding of school policies and practices and other students, staff, and faculty may not be readily accessible that can provide students with the information that they seek. Consequently, the e-learning system should contain detailed information about the school, educational programs, and courses that is immediately accessible to students as well as an online student manual that covers the elearning system in detail. Moreover, the names, e-mail addresses, and phone numbers of online instructors, advisers, and technicians should be readily available. E-mail that school personnel receive from students should be quickly answered or, if that is not possible, the 
student should receive e-mail that acknowledges receipt of each student query and provides a date when the student can expect a full reply.

The next distance learner need identified by Workman and Stenard (1996) is self-esteem. They suggested learning may be slow until students develop a heightened sense of selfesteem. A distance learning program can build self-esteem by requiring students to participate in an orientation program prior to their first course that includes mastery of the online tools used in the e-learning system. Additionally, positive self-esteem can be nurtured during coursework by identifying precisely stated and measurable learning objectives and providing students with timely teacher-to-student and student-to-student feedback regarding mastery of these objectives.

The third need is to feel an identity with the school so students do not view themselves as outsiders. This need is closely related to sense of community and what Tinto (1993) refers to as institutional commitment. Workman and Stenard (1996) suggested that a simple but effective way of establishing identification with the school is to issue identification cards. Such cards can facilitate entry into school facilities when personnel are on campus and can offer discounts from various online merchants, particularly those selling books, computers, and software. More importantly, these cards provide online students with a connection to the college.

The fourth need is the requirement for social integration, that is, the need for students to develop interpersonal relationships with peers, faculty, and staff. This need is also closely related to sense of community. Kember, Lai, Murphy, Siaw, and Yuen (1992) provided evidence to suggest that in distance education classes "students who achieve social integration find it easier to come to terms with their academic demands" (p. 296).

The final student need identified by Workman and Stenard (1996) is the requirement for ready access to support services such as bookstores, library, financial aide offices, and advisers. They suggested that distance learners also value services such as tutoring, study skill training, and particularly an orientation on the technology used for course delivery. The distractions created by technology must be minimized. Consequently, telephone service is often more user friendly and more effective for online students than is interactive computing for responding to student problems and advising students.

Online students also expect a pedagogy that matches their learning style. Kerka (1996, p. 1) wrote that the medium used for online distance education courses "supports self-directed learning-computer conferencing requires learner motivation, self-discipline, and responsibility." Grow (1996) developed a model for matching a student's self-direction ability with teaching style. Although Grow did not extend his model beyond teaching style, it is possible that his model might also be used to match self-direction with the distance education delivery mode. He theorized that as students become more self-directed, both the teaching style and the curriculum can become less directive. As self-directed learners, students should have the ability to: (a) identify and set personally meaningful goals for their own learning; (b) develop and use a wide range of learning strategies appropriate to different learning tasks; (c) work independently and with others to achieve their learning goals; and (d) persist to overcome obstacles in order to achieve their learning goals (Radloff \& de la Harpe, 1999, as cited in Price, 2000). Students who are not self-directed 
will likely perform better in a lecture format, while students who are self-directed can do independent projects with the teacher functioning more as a consultant. Self-directed learning recognizes the significant role of both motivation and volition in initiating and maintaining learners' efforts.

Sherry (1996) reported that students at a distance are required to take greater responsibility for their own learning, as online learning results in greater learner control and learnercenteredness. Accordingly, learner autonomy, that is, the concept of independence and selfdirection, has been a hallmark of adult education and an assumed characteristic of the nontraditional students enrolled in distance education programs. Moore and Kearsley (1996) suggested that online students will perform better if they utilize a self-directed, informationseeking approach. Such self-directed learning is often described as "a process in which individuals take the initiative, with or without the help of others, to diagnose their learning needs, formulate learning goals, identify resources for learning, select and implement learning strategies, and evaluate learning outcomes" (Knowles, 1975, p. 10). In traditional courses, students tend to rely on the instructor for all content and assignment reminders. However, there is a greater responsibility on the online student for organizing his or her time and meeting all deadlines. Students who lack self-direction and self-discipline and are dependent learners may be less likely to succeed in online courses, particularly if the instructor manifests the teaching styles of a facilitator, consultant, and delegator rather than that of an authority and coach (Grow, 1996).

To promote self-directed learning in students, Taylor (1995) suggested involving students in decisions concerning what is to be learned, when and how it should be learned, and how it should be evaluated. In addition, learners should be allowed to pursue their own interests so that learning becomes more meaningful. However, the research on the role of self-direction in online learning is mixed. The image of the capable adult distance learner may not be accurate (Paul, 1988). The experiences of many distance educators have revealed that part-time adult distance learners require all the support they can get to succeed. Paul (1988, p. 50) wrote “...distance education institutions bear considerable responsibility for helping its students to cope with the difficulty inherent in this model of education." Moreover, some studies characterized the successful distance student as an autonomous, independent learner (e.g., Tucker, 2000), but others found no correlation between learning style and learning outcomes. There is a growing belief that self-directed learning is situational, that it is not always the best approach of instruction for all adults, and that there are times, places, and circumstances when it should not be used at all (Grow, 1996). Such a belief supports the view that online courses should support multiple learning styles.

\section{Conclusion}

There is no simple formula that ensures student persistence. Adult persistence in an online program is a complicated response to multiple issues. It is not credible to attribute student attrition to any single student, course, or school characteristic. There are numerous internal 
and external factors that come into play, as well as interactions between factors. Houle (1961, p. 80) wrote,

Efforts to explore the reasons why some people become continuing learners has made it clear that there is no simple answer to this complex question. Each person is unique and his [or her] actions spring from a highly individualized and complex interaction of personal and social factors.

However, there is a growing consensus on several important factors to explain persistence in online programs. These factors are included in the composite model shown in Fig. 3. Administrators of distance education programs should be able to use this model to help them identify students who are at risk to become dropouts. Additionally, this model can be used to identify topics for student interventions.

Deficiencies in academic preparation and online student skills can be remedied through early intervention efforts. Remediation and integration efforts can be presented either online or on-campus in a hybrid blend of face-to-face and distance education technologies. Hybrid programs promise the best of both worlds, offering most of the convenience of all-online programs without the complete loss of face-to-face contact. The hybrid model assumes that online learning can be enhanced during one or more face-to-face sessions that foster academic and social integration with the school. Accordingly, an initial face-to-face residency that precedes an online program can be used to deliver early intervention programs, to include addressing prerequisite deficiencies in computer and information literacy and student reading, writing, and study skills. Additionally, such programs can introduce students to the school and its services and help integrate them into the academic and social life of the school, similar to a "freshman experience" orientation.

Once students enroll in an online program, the composite model identifies important external factors that help explain student persistence. Regardless of students' academic preparation and existing skills, if they cannot pay for college, make adequate child care arrangements, or adjust their work schedules, they are unlikely to persist in school. College administrators should therefore ease external risk factors (i.e., nonschool factors that conflict with academic life) in helping students realize their educational aspirations. This goal can be achieved through outreach programs that make students aware of college programs and services and provide support, such as counseling services, for students who are concerned about whether or not they made the right choice in pursuing a college education.

Internal factors after admission are also important. Students' involvement in and attachment to their school are essential elements for success. Accordingly, the first year experiences of new online students are critical. Early counseling is essential to establish expectations and to give a sense of the college community (Cullen, 1994). These experiences should quickly dispel any assumptions by students that online courses are easier, less demanding, or less time-consuming than regular courses (Hardy \& Boaz, 1997). There is also an important need to create a learning community (e.g., Rovai, 2001; Tinto, 1987) that encompasses the needs of all students, connects them to each other, to the institution, and to the resources that they need to succeed, and allows them to get responsive help (Workman \& Stenard, 1996). Most successful retention efforts include program elements that focus on increasing academic 
integration consisting of active participation and satisfactory experiences where students personally interact with faculty and each other. Personal attention, a staff willing to listen, frequent contact with the faculty, and assistance with personal and financial problems are hallmarks of an effective online program (Smith \& Bailey, 1993).

Success in online courses typically requires a high level of discipline and self-direction, and enough time each week to complete all assignments. Comprehensive, multicomponent strategies are required. There is a need to avoid simply providing information to online students. Good instructional design and pedagogy are at the core of high-quality online courses. Moreover, good instruction tailored to the medium and to the learning needs and styles of the students served is required.

The experiences of an unfamiliar learning environment demand significant coping skills for nontraditional learners. It may be necessary for online learners to develop a repertoire of learning styles, and for online faculty to encourage that development. Because classes do not meet in the traditional sense, some students must be motivated to begin course work on time, keep up with assignments, and actively participate. Besides learning from course materials and their online instructors, students should also be encouraged to learn from each other, and schools delivering instruction at a distance should actively encourage the formation of study groups among online learners. An initial face-to-face residency can be a great opportunity to address these coping skills and facilitate the formation of informal study groups for new online students. All such efforts have the potential to increase persistence.

\section{References}

American Library Association Presidential Committee on Information Literacy (1989). Information power: building partnerships for learning. Final report. Chicago: American Library Association.

Ashar, H., \& Skenes, R. (1993). Can Tinto's student departure model be applied to nontraditional students? Adult Education Quarterly, 43, 90-100.

Bean, J., \& Metzner, B. (1985). A conceptual model of nontraditional undergraduate student attrition. Review of Educational Research, 55, 485-650.

Borrego, A. M. (2002, July 1). Today's news: education department will emphasize retention issues in next higher education act, official says. The Chronicle of Higher Education. Retrieved July 1, 2002, from The Chronicle of Higher Education Website: http://chronicle.com/daily/2002/07/2002070102n.htm.

Cabrera, A., Castaneda, M., Nora, A., \& Hengstler, D. (1992). The convergence between two theories of college persistence. Journal of Higher Education, 63(2), 143-164.

Carr, S. (2000, February 11). As distance education comes of age, the challenge is keeping the students. The Chronicle of Higher Education, A39-A41.

Cole, R. A. (Ed.) (2000). Issues in web-based pedagogy: a critical primer. London: Greenwood Press.

Corno, L., \& Kanfer, R. (1993). The role of volition in learning and performance. Review of Research in Education, 19, 301-341.

Cullen, M. (1994). Weighing it up: a case study of discontinuing access students. Edinburgh, Scotland: University of Edinburgh. (ERIC Document Reproduction Service No. ED379406).

Fishbein, M., \& Ajzen, I. (1975). Belief, attitude, intention and behavior: an introduction to theory and research. Reading, MA: Addison-Wesley.

Graham, G. W., \& Gisi, S. L. (2000). Adult undergraduate students: what role does college involvement play. NASPA Journal, 38(1), 99-122. 
Grow, G. O. (1996). Teaching learners to be self-directed. Adult Education Quarterly, 41(3), 125-149.

Hardy, D., \& Boaz, M. (1997). Learner development: beyond the technology New directions for teaching and learning, vol. 71. San Francisco: Jossey-Bass.

Hashway, R. M., Baham, C., Hashway, S. E., \& Rogers, R. M. (2000). Retaining students in college. Educational Research Quarterly, 23, 35-59.

Heckhausen, H., \& Kuhl, J. (1985). From wishes to action: the dead ends and short cuts on the long way to action. In M. Frese, \& J. Sabini (Eds.), Goal directed behavior: the concept of action in psychology (pp. 134-157). Hillsdale, NJ: Lawrence Erlbaum Associates.

Henry, T. C., \& Smith, G. P. (1993). Planning student success and persistence: implementing a state system strategy. Community College Review, 22(2), 26-36.

Horn, L., \& Premo, M. (1995). Profile of undergraduates in U.S. postsecondary education institutions: 1992-93. Washington, DC: U.S. Department of Education, National Center for Education Statistics.

Houle, C. O. (1961). The inquiring mind: a study of the adult learner who continues to participate to learn. Madison, WI: University of Wisconsin Press.

Kember, D., Lai, T., Murphy, D., Siaw, I., \& Yuen, K. (1992). Student progress in distance education: identification of explanatory constructs. British Journal of Educational Psychology, 62, 285-298.

Kerka, S. (1996). Distance learning, the Internet and the World Wide Web. ERIC Digest. (ERIC Document Reproduction Service No. ED395214). Retrieved July 14, 2002, from http://www.ed.gov/databases/ERIC_Digests/ ed395214.html.

Knowles, M. (1975). Self-directed learning: a guide for learners and teachers. New York: Association Press.

Koutsoubakis, D. (1999). A test of the effectiveness of a one-term freshmen orientation program at the foreign campus of an accredited private American university. Journal of the First-Year Experience, 11, $33-58$.

Maxwell, W. (1998). Supplemental instruction, learning communities, and students studying together. Community College Review, 26, 1-18.

Metzner, B. S., \& Bean, J. P. (1987). The estimation of a conceptual model of nontraditional undergraduate student attrition. Research in Higher Education, 27(1), 15-38.

Moore, M. G., \& Kearsley, G. (1996). Distance education: a systems view. Belmont, CA: Wadsworth Publishing Company.

Murguia, E., Padilla, R. V., \& Pavel, M. (1991). Ethnicity and the concept of social integration in Tinto's model of institutional departure. Journal of College Student Development, 32, 433-439.

Parker, S., \& Greenlee, H. (1997). From numbers to action: a preliminary study of retention. Paper presented at the Annual Forum of the Association for Institutional Research, Albuquerque, NM. (ERIC Document Reproduction Service No. ED397721).

Pascarella, E. T., \& Terenzini, P. T. (1991). How college affects students: findings and insights from twenty years of research. San Francisco: Jossey Bass.

Paul, R. (1988). If student services are so important, then why are we cutting them back? In D. Sewart, \& J. S. Daniel (Eds.), Developing distance education. Paper submitted to the 14th ICDE World Conference, Oslo, August 1988. Oslo: International Council for Distance Education.

Price, C. (2000). Self directed learning in first year physiotherapy students: reflections. In A. Herrmann, \& M. M. Kulski (Eds.), Flexible futures in tertiary teaching. Proceedings of the 9th Annual Teaching Learning Forum, 2-4 February 2000. Perth: Curtin University of Technology (Retrieved July 14, 2002, from http://cea.curtin. edu.au/tlf/tlf2000/price.html).

Quigley, B. (1997). Rethinking literacy education: the critical need for practice-based change. San Francisco: Jossey-Bass.

Radloff, A., \& de la Herpe, B. (1999). Characteristics of self directed learners in the context of the self directed learning project (Self Directed Learning Workshop). Perth, Western Australia: Curtain University of Technology.

Rendon, L., Jalomo, L., \& Nora, A. (2000). In Braxton J. M. (Ed.), Reworking the student departure puzzle (pp. 127-156). Nashville: Vanderbilt Univ. Press. 
Ross, L. R., \& Powell, R. (1990). Relationships between gender and success in distance education courses: a preliminary investigation. Research in Distance Education, 2(2), 10-11.

Rovai, A. P. (2001). Building classroom community at a distance: a case study. Educational Technology Research and Development Journal, 49(4), 35-50.

Rowntree, D. (1995). Teaching and learning online. A correspondence education for the 21 st century? British Journal of Educational Technology, 26(3), 205-215.

Schlosser, C. A., \& Anderson, M. L. (1994). Distance education: review of the literature. Washington, DC: Association for Educational Communications and Technology.

Sherry, L. (1996). Issues in distance learning. International Journal of Educational Telecommunications, 1(4), 337-365.

Smith, G., \& Bailey, V. (1993). Staying the course. London: Business and Technology Education Council, 1993. (ERIC Document Reproduction Service No. ED359356).

Snyder, T. D., \& Hoffman, C. M. (2002). Digest of education statistics 2001 (NCES Report No. NCES 2002-130). Washington, DC: U.S. Department of Education, National Center for Education Statistics.

Taylor, B. (1995, Nov. 11-15). Self-directed learning: revisiting an idea most appropriate for middle school students. Paper presented at the Combined Meeting of the Great Lakes and Southeast International Reading Association, Nashville, TN. (ERIC Document Reproduction Service No. ED395287).

Tinto, V. (1975). Dropout from higher education: a theoretical synthesis of recent research. Review of Educational Research, 45(1), 89-125.

Tinto, V. (1987). Leaving college. Chicago: University of Chicago Press.

Tinto, V. (1993). Leaving college: rethinking the causes and cures of student attrition. Chicago: University of Chicago Press.

Tucker, S. Y. (2000). Assessing the effectiveness of distance education versus traditional on-campus education. Paper presented at the Annual Meeting of the American Educational Research Association, New Orleans, LA. (ERIC Document Reproduction Service No. ED443378).

Villella, E. F., \& Hu, M. (1991). A factor analysis of variables affecting the retention decision of nontraditional college students. NASPA Journal, 28(4), 334-341.

Wolf-Wendel, L. E., Tuttle, K., \& Keller-Wolff, C. M. (1999). Assessment of a freshman summer transition program in an open-admissions institution. Journal of the First-Year Experience, 11, 7-32.

Wood, H. (1996). Designing study materials for distance students. Learning Materials Centre. Retrieved November 25, 2002, from http://www.csu.edu.au/division/0LI/di-rd/occpap17/design.htm.

Workman, J. J., \& Stenard, R. A. (1996). Student support services for distance learners. DEOSNEWS, 6(3) (Retrieved July 3, 2002, from the Distance Education Online Symposium Website: http://www.ed.psu.edu/ acsde/deos/deosnews/deosnews6_3.asp).

Yorke, M. (1999). Leaving early: undergraduate non-completion in higher education. London: Falmer Press. 